powers and university title are met. In Nigeria, online degrees from unaccredited institutions are banned and employers are not supposed to accept fraudulent degrees. In Australia, the term "university" is protected.

\section{INTERNATIONAL ACTION}

The recent focus on degree mills accompanies work on academic quality as higher education is increasingly internationalized. In Study Abroad, UNESCO published the CHEA Fact Sheet on degree mills and accreditation mills developed in 2003 as part of its alerts to this phenomenon. UNESCO and the Organization of Economic Cooperation and Development issued Guidelines for Quality Provision of Cross-Border Higher Education in 2005. The Guidelines suggest tasks for the various stakeholders in higher education - to protect quality for crossborder higher education provision to safeguard against degree mills. UNESCO has also recently launched a pilot, Portal on Higher Education Institutions, that provides international access to reliable countrywide lists of legitimate higher education providers (http://www.unesco.org/education/portal/hedinstitutions). This positive listing makes it clear that institutions that are not included may be suspect.

The international group brought together by CHEA and UNESCO is working on an international effective practices statement to address the problem of degree mills. The group is also exploring additional strategies such as whether a permanent international effort is needed to address rogue providers and the feasibility of an ongoing international campaign to raise public awareness.

This international effort is an ongoing need. Degree mills will continue to be a problem for students, employers, government, and higher education. They put a vital resource of our countries at risk-namely, our extensive, diverse, and highly effective higher education enterprise and the students who are served.

\section{When Criminals Control the Ministry of Education}

\section{George D. Gollin}

George D. Gollin is professor of physics at the University of Illinois and a member of the Board of Directors of the Council for Higher Education Accreditation. Address: Department of Physics, University of Illinois at Urbana-Champaign, Urbana, IL 61801, USA. E-mail: g-gollin@uiuc.edu.

$\mathrm{T}$ he connection between education and personal economic advantage drives a global market for higher education. But much of the world cannot create additional university capacity at a rate to match this demand. Diploma mills, businesses that sell bogus degrees to customers in search of easy credentials, comprise the dark response to these market forces. The recent demise of a sophisticated American diploma mill provides some insight into these abominations.

\section{Paying Bribes to Great Effect}

In 2002, Richard Novak traveled to Washington DC to bribe a diplomat. Perhaps his experience as a car salesman in Arizona served him well: he convinced Abdulah Dunbar, the Liberian embassy's deputy chief of mission, to sell Liberian university accreditation to "St. Regis University" for \$2,250, considerably less than Dunbar's original demand for $\$ 4,000$. This first transaction opened a conduit through which Dixie and Steve Randock, the American owners of the St. Regis diploma mill, began channeling payments and incentives to Liberian officials.

The recent demise of a sophisticated American diploma mill provides some insight into these abominations.

At that time Liberia was still a year from the end of its bloody civil war. Mean life expectancy was 38 years, and infant mortality was I5 percent. Much of Liberia's infrastructure had been destroyed. Into this desperate landscape the Randocks pretended to insert three universities: St. Regis, Robertstown, and James Monroe. Their Web sites invited customers to contact Dunbar in Washington or Andrew Kronyanh at Liberia's embassy in Ghana, for verification of the schools' legitimacy. All three mills claimed to be in Monrovia; a doctored campus photograph showed a beautiful building in a pastoral setting. But this was really Blenheim Palace, birthplace of the very English Winston Churchill.

\section{Hijacking the Ministry of Education}

Dunbar was dismissed from the Liberian embassy in June 2003, complicating his task of vouching for St. Regis. The Randocks sent Novak and Dunbar to Africa two months later "with the specific intent to carry out the appropriate tasks placing [Dunbar] into the appropriate Liberian political office." The Randocks successfully achieved their ends: Dunbar was returned to Washington a few months later as the embassy's chief of mission.

By the end of 2003 the Randocks had come to control the Ministry of Education's list of recognized colleges and universities, as well as the content of the Liberian embassy's Web site. Through their officially sanctioned "National Board of Education," they sold Liberian accreditation directly to other diploma mills such as "Southern Pacific University" and "American Coastline University." Liberian officials under their 
sway included senior diplomats in at least two embassies, a minister of justice, a foreign minister, two successive directors of Liberia's National Commission for Higher Education, and a number of other diplomats and government officials, including several at the Ministry of Education.

\section{You Too Can OWn a University!}

The following year the Randocks expanded their product line to include prefabricated diploma mills, pitching them this way: "Do you want to make MILLION\$ by owning your own online school, college or university? ... OUR EXPERTS CAN HELP YOU DO IT!" They informed prospective customers that their "expert consultants have established long term relationships with the proper authorities, which will substantially shorten the time it would normally take to establish a new school or to gain legitimate accreditation [for] your existing school."

In July 2005, Richard Novak flew to Washington DC to meet with three investors interested in purchasing accreditation and other services for "Randolph Addison Davis Technical University." Four hours into the meeting Abdulah Dunbar (the "proper authority," no doubt) arrived to discuss his fee for services to be rendered. But the investors were actually United States Secret Service agents and RADTU was a ruse.

\section{The End of St. Regis}

A month later federal, state, and local authorities raided the St. Regis enterprise, confiscating computers and degree-making paraphernalia at seven sites in Arizona, Idaho, and Washington state. By then the Randocks had sold thousands of degrees to customers all over the world. They had even appropriated the name "Thomas Carper" (a US senator from the state of Delaware) for the president of St. Regis. And the min-

Four hours into the meeting Abdulah Dunbar (the "proper authority," no doubt) arrived to discuss his fee for services to be rendered. But the investors were actually United States Secret Service agents and RADTU was a ruse.

isterial recognition of many of the "universities" whose names the Randocks printed on diplomas was functionally equivalent to that of the legitimate University of Liberia.

Richard Novak, the Randocks, and five other defendants were indicted in October 2005 on a mix of criminal charges that included mail and wire fraud, money laundering, and bribery of foreign officials. Kenneth Pearson, the St. Regis Web master, was indicted on additional child pornography charges a few months later: the St. Regis servers also held thousands of pornographic images. All eight defendants chose to plead guilty, the last in April 2008, rather than face a jury trial.
Degree-granting authority does not guarantee academic legitimacy. Was St. Regis a legitimate university? Of course not. No classes were taught and none of the Randocks' employees who fabricated transcripts and diplomas for customers had finished high school. The fact that the Randocks had purchased "accreditation" from the same officials who would issue recognition to genuine Liberian universities cannot change this.

But did their Liberian recognition actually invest them with the legal authority to award degrees? Again, the answer is no, since the Randocks sold degrees from Washington state and Idaho (rather than Liberia) and had never been licensed by either Washington or Idaho. The situation would have become more complicated if St. Regis had relocated its servers and administrative infrastructure to Liberia or Ghana. It still would have been a diploma mill, but it might have been able to operate in compliance with Liberian law.

Possession of degree-granting authority issued by an appropriate government agency is a necessary, but not sufficient, condition for a school to be legitimate.

We have a problem of similar shape in the United States, where degree-granting authority stems from individual states with varying standards. For example, Alabama's Department of Postsecondary Education sometimes issues private school operating licenses without adequate attention to the practices of those schools. One organization with such a license claimed "accreditation" from an accreditation mill run by the school's owner; his accreditation mill also issued credentials to bogus medical schools. A few years before obtaining an Alabama license, he had partnered with the Randocks' organization so that his clients would receive diplomas from his school and also from St. Regis.

Possession of degree-granting authority issued by an appropriate government agency is a necessary, but not sufficient, condition for a school to be legitimate. Any international agreement that governs recognition of academic degrees across borders must be robust to problems arising from the distinction between legitimacy and legal compliance.

This is not a simple, static issue. The changing circumstances that can threaten to destabilize countries such as Chad and the Central African Republic make their governments targets for the operators of diploma mills. And the pressing need for increased higher education capacity in the developing world creates a market that is hugely attractive to diploma mills. It will be the task of the international higher education community to develop the vetting and database tools necessary to address this. 